\title{
MODIFIED RITGEN MANEUVER IN PERINEAL PROTECTION - SIXTY-YEAR EXPERIENCE
}

\author{
Dubravko Habek ${ }^{1}$, Ana Tikvica Luetić ${ }^{1}$, Ingrid Marton ${ }^{1}$, Matija Prka ${ }^{1}$, \\ Goran Pavlović ${ }^{2}$ Ž́eljka Kuljak ${ }^{1}$, Deana Švanjug ${ }^{3}$ and Zdenka Mužina ${ }^{2}$ \\ ${ }^{1}$ University Department of Obstetrics and Gynecology, Sveti Duh University Hospital, \\ Croatian Catholic University, Zagreb, Croatia; ${ }^{2}$ Department of Obstetrics and Gynecology, \\ Bjelovar General Hospital, Bjelovar, Croatia; ${ }^{3}$ University of Rijeka, Faculty od Health Sciences, Rijeka, Croatia
}

\begin{abstract}
SUMMARY - The aim is to present the 60-year experience in modified Ritgen maneuver according to perineal injuries. This retrospective clinical observational study (1950-2010) analyzed the impact of modified Ritgen maneuver delivery technique (controlled fetal head deflexion with left hand and synchronous reduction of perineal strain with extended right hand thumb along the right side of the vulva and perineum without pushing) on peripartum perineal tears at the Maternity Ward, Bjelovar General Hospital in Bjelovar, Croatia, divided into five-year intervals. The rate of perineal tear in general was less than $5 \%$ until 2000 . The rate of perineal tear grade I was very low until 1995, then increased to $8.6 \%$ in 2010 , yet never exceeding $10 \%$. The rate of perineal tear grade II never exceeded $2 \%$, whereas perineal tear grade III was a sporadic event never exceeding $0.4 \%$ of the study material with a single case of grade IV tear. The rate of intact perineum in vaginal deliveries without episiotomy ranged from $96.2 \%$ to $100 \%$ in the $1950-1960$ period, with a decrease to $46 \%$ in 2010 . The study revealed the modification of Ritgen maneuver described to have resulted in significant reduction of all grades of perineal tear over decades.
\end{abstract}

Key words: Delivery, obstetric; Perineum - injuries; Anal canal-injuries; Lacerations - prevention and control; Croatia

\section{Introduction}

Soranus was the first to propose perineal compresses to support the perineum and to prevent tears of the soft birth canal during fetal head passage ${ }^{1}$. Manual perineal protection (MPP) has grown into a midwifery/obstetric skill that has undergone modifications over time ${ }^{1}$. Martius has suggested that perineal elasticity be used on MPP to prevent abrupt fetal head deflexion and subsequent perineal injury ${ }^{2}$. It has been shown that the outcome of MPP is influenced by many factors such as perineal height and elasticity, size

Correspondence to: Prof. Dubravko Habek, $M D, P h D$, University Department of Obstetrics and Gynecology, Sveti Duh University Hospital, Croatian Catholic University, Sveti Duh 64, HR-10000

Zagreb, Croatia

E-mail: dhabek@unicath.hr

Received March 27, 2017, accepted January 31, 2018 of fetal head, shape of pubic arch, labor pain intensity and strain, parturient's position, parturient's mental state, and perineal protection technique ${ }^{2}$. Ritgen introduced an original manual perineal protection (RMPP) with upward pressure upon the 'posterior perineum', so that the left hand slows down the head and controls deflexion, while softly lifting fetal chin with the second to fourth fingers of the right hand over posterior perineum (between the coccygeal region and anus), both resulting in gradual deflection of the head (Fig. 1). In case of impossible reaching fetal chin, Ohlshausen has suggested it to be done by inserting two fingers into the rectum, but this maneuver is rarely performed ${ }^{3}$. RMPP is recommended to be done when fetal head has already extended the introitus to about $5 \mathrm{~cm}$ without turning backward between labor pains. Martius has also recommended the use of RMPP when fetal head does not return during labor pain and then the 


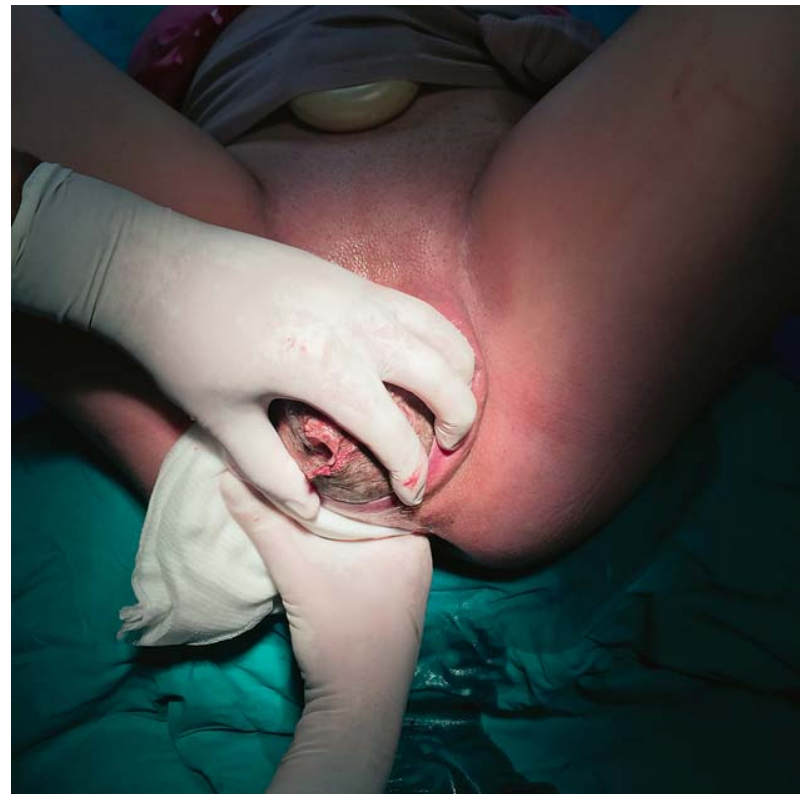

Fig. 1. Modified Ritgen manual perineal protection.

parturient should not push but fetal head should be delivered by the midwife/obstetrician in millimeters over the perineum in-between two labor pains. Using the maneuver described, head should be delivered by its smallest diameter avoiding abrupt passage, while the forehead should be delivered during the pause between two labor pains ${ }^{2}$. The same procedure has also been recommended by Pschyrembel and Dudenhausen, with special consideration of using the same procedure on delivering posterior shoulder with perineal support because inappropriate perineal support on posterior shoulder delivery could be the cause of extensive perineal tears ${ }^{4}$. The Anglo-Saxon obstetric textbook also recommends modified RMPP in controlled head deflexion ${ }^{5}$.

A recent Scandinavian model of MPP technique recommends a combination of RMPP and conventional perineal protection by bimanual technique: the right hand is spread on the perineum so that the index finger and thumb 'squeeze' the perineum, while the third finger lifts fetal chin (or nose) up while at the same time preventing abrupt deflexion with the left hand; the parturient should not push, and fetal head is released over the perineum in-between labor pains ${ }^{5}$.

The aim is to present the 60-year experience in vaginal deliveries using modified Ritgen manual perineal protection (MRMPP) technique according to peripartum tears of the soft birth canal.

\section{Material and Methods}

This retrospective clinical observational study was focused on the impact of MRMPP on the peripartum perineal injury during a 60-year period (January 1, 1950 to December 31, 2010) at the Maternity Ward, Bjelovar County General Hospital in Bjelovar, a town in north-west Croatia. Considering the great number of deliveries and comparable results recorded throughout the study period (1950-2010), the results were analyzed in five-year intervals. The following parameters were extracted from obstetric protocols and investigated: total number of deliveries, cesarean sections and episiotomies, number of intact perineum, and number of soft birth canal tears: vaginal and perineal tears grades I-III according to the actual classification per number of vaginal deliveries per year. Rectal tears were classified as grade IV according to the current Sultan et al. classification ${ }^{6}$, while clitoris, periurethral tissue and labium minus tears were considered as anterior tears.

The study was approved by the institutional Ethics Committee. Data were processed using Microsoft Excel calculator, SPSS and statistical analysis with $\chi^{2}$-test and percent calculation. The level of statistical significance in relation to the initial survey results was set at $\mathrm{p}<0.001$.

The MRMPP (Fig. 1) was performed respecting the following conditions and elements: the parturient is lying supine with her legs leaning laterally on the bed side rails, her pelvis is lifted, without leg hyperflexion, thus reducing additional perineal strain, or in another labor position enabling MRMPP; fetal head must 'fit' onto the perineum without turning back to the vagina in-between labor pains, thus gradually opening vaginal introitus. Fetal head is supported by the left hand preventing abrupt deflexion, while the right hand thumb is extended along the right side of the vulva and perineum with gauze covering the anus but leaving perineal edge visible. In this way, fetal chin is gradually moved over posterior perineum upward with the forefinger and other fingers and synchronously delivered with the left hand. Such positioning of the fingers prevents full perineal strain; instead, it is contracted and relaxed in parallel with fetal head elevation, thus preserving its elasticity; fetal head is released in-between labor pains, without maternal pushing and the same procedure is applied on posterior shoulder delivery. 
Table 1. Obstetric statistics data of the Maternity Ward, Bjelovar General Hospital, 1950-2010

\begin{tabular}{|l|l|l|l|l|l|}
\hline Year & $\begin{array}{l}\text { Total number } \\
\text { of deliveries }\end{array}$ & $\begin{array}{l}\text { Vaginal } \\
\text { deliveries, } \mathrm{n}\end{array}$ & $\begin{array}{l}\text { Cesarean } \\
\text { section, n (\%) }\end{array}$ & $\begin{array}{l}\text { Episiotomy, } \\
\mathrm{n}(\%)\end{array}$ & $\begin{array}{l}\text { Intact } \\
\text { perineum, \% }\end{array}$ \\
\hline 1950 & 300 & 300 & 0 & 0 & 100 \\
1955 & 525 & 521 & $4(0.7)$ & $3(0.5)$ & 96.2 \\
1960 & 798 & 790 & $18(2.0)$ & $155(19.7)$ & 76.0 \\
1965 & 1130 & 1117 & $13(1.1)$ & $190(17.0)$ & 76.9 \\
1970 & 964 & 952 & $12(1.2)$ & $59(6.1)$ & 88.5 \\
1975 & 1173 & 1149 & $24(2.0)$ & $187(16.1)$ & 76.5 \\
1980 & 1242 & 1191 & $51(4.1)$ & $252(21.1)$ & 73.6 \\
1985 & 1158 & 1090 & $68(5.8)$ & $241(22.1)$ & 74.5 \\
1990 & 899 & 839 & $60(6.6)$ & $334(39.8)$ & 53.9 \\
1995 & 1176 & 1080 & $96(8.1)$ & $379(35.1)$ & 55.8 \\
2000 & 780 & 695 & $85(10.9)$ & $239(34.3)$ & 61.2 \\
2005 & 767 & 648 & $119(15.5)$ & $300(46.2)$ & 39.3 \\
2010 & 742 & 593 & $149(20.1)$ & $196(33.0)$ & 46.7 \\
\hline
\end{tabular}

During the study period, no oil or other devices for antenatal perineal massage, or warm perineal compresses were used. Moist sterile gauze was applied on the perineum after disinfection, while waiting very patiently as to neither speed up nor slow down the second labor stage of physiologic delivery without extensive fundal pressure. All women delivered in supine position with elevated head bolster and slightly elevated back, and with elevated pelvis without leg hyperflexion at the end of the second labor stage. Mothers were discharged from the hospital on the parturient day 3 or 4 if no other complications occurred. At the maternity ward of Bjelovar County General Hospital, MRMPP was used as a delivery technique based on the individualized, calm and gentle approach to each pregnant woman.

\section{Results}

There was a striking linear increase in the rate of cesarean sections and episiotomies from 1960 $(p<0.001)$ and then again since 2005, which was due to changes in the obstetric and midwifery staff $(p<0.001)$; after that, the number of episiotomies decreased by more than $10 \%$, along with constant decline in the number of deliveries since 1995 (Table 1). The rate of perineal tear was less than 5\% until 2000, after which it increased twofold $(\mathrm{p}<0.001)$. The rate of perineal tear grade I was very low until 1995, then it increased to $8.6 \%$ in 2010 , yet never exceeding $10 \%$ (Table 2). In the study period, the rate of perineal tear grade II never exceeded $2 \%$, whereas perineal tear grade III (obstetric anal sphincter injuries, OASIS) according to the old nomenclature was a sporadic event never exceeding $0.4 \%$ of the study material. A single case of rectal tear (grade IV according to current classification) was recorded in 1970 (Table 2). The rate of intact perineum in deliveries without episiotomy in the total number of vaginal deliveries ranged from $96.2 \%$ to $100 \%$ in the initial study years, then decreased to $70 \%$ $80 \%$ in the next three decades, and to $53 \%-61 \%$ in the 1990-2000 period. The percentage of vaginal deliveries with intact perineum decreased to only 39\% in 2005 and then to $46 \%$ per 11,654 deliveries in 2010 $(\mathrm{p}<0.001)$ (Table 1).

\section{Discussion}

Our previous research into the history of midwifery and obstetrics through delivery protocols of the Maternity Ward in Bjelovar Hospital revealed a low incidence of perineal tear over decades, as well as a low incidence of episiotomy ${ }^{1}$. This result was confirmed in the current study that analyzed a 60 -year period showing excellent traditional midwifery knowledge and skills such as MRMPP. The MRM described definite- 
Table 2. Obstetric statistics data of the Maternity Ward, Bjelovar General Hospital, 1950-2010: anterior, vaginal and perineal lacerations

\begin{tabular}{|l|l|l|l|l|l|l|}
\hline Year & $\begin{array}{l}\text { Anterior } \\
\text { laceration, } \\
\mathrm{n}(\%)\end{array}$ & $\begin{array}{l}\text { Vaginal } \\
\text { laceration, } \\
\mathrm{n}(\%)\end{array}$ & $\begin{array}{l}\text { Perineal } \\
\text { laceration } \\
\text { grade I, } \\
\mathrm{n}(\%)\end{array}$ & $\begin{array}{l}\text { Perineal } \\
\text { laceration } \\
\text { grade II, } \\
\mathrm{n}(\%)\end{array}$ & $\begin{array}{l}\text { Perineal } \\
\text { laceration } \\
\text { grade III, } \\
\mathrm{n}(\%)\end{array}$ & $\begin{array}{l}\text { Laceration } \\
\text { grade IV, } \\
\mathrm{n}(\%)\end{array}$ \\
\hline 1950 & 0 & 0 & $3(0.1)$ & 0 & 0 & 0 \\
1955 & 0 & $2(0,3)$ & $9(1.7)$ & 0 & 0 & 0 \\
1960 & 0 & $17(2.1)$ & $11(1.4)$ & $3(0.3)$ & $3(0.3)$ & 0 \\
1965 & $2(0.1)$ & $33(2.9)$ & $20(1.7)$ & $9(0.8)$ & $3(0.3)$ & 0 \\
1970 & $3(0.3)$ & $23(2.4)$ & $20(2.1)$ & $3(0.3)$ & 0 & $1(0.1)$ \\
1975 & $3(0.2)$ & $40(3.4)$ & $37(0.1)$ & $2(0.08)$ & $1(0.08)$ & 0 \\
1980 & $2(0.1)$ & $30(2.5)$ & $23(1.9)$ & $7(0.5)$ & 0 & 0 \\
1985 & $2(0.1)$ & $17(1.5)$ & $16(1.4)$ & $1(0.0)$ & 0 & 0 \\
1990 & $4(0.4)$ & $24(2.8)$ & $19(2.2)$ & $5(0.6)$ & 0 & 0 \\
1995 & $3(0.2)$ & $48(4.4)$ & $37(3.4)$ & $11(1.0)$ & 0 & 0 \\
2000 & $4(0.5)$ & $63(9.0)$ & $61(8.7)$ & $2(0.2)$ & 0 & 0 \\
2005 & $5(0.7)$ & $44(6.7)$ & $38(5.8)$ & $6(0.9)$ & 0 & 0 \\
2010 & $4(0.6)$ & $58(9.7)$ & $51(8.6)$ & $7(1.1)$ & 0 & 0 \\
\hline
\end{tabular}

ly includes synchronous reduction of perineal strain and controlled fetal head deflexion resulting in significant reduction of perineal tear of all grades over decades in spite of the increase in the rate of cesarean section and episiotomy in the last decade (Tables 1 and 2). Although our research may have been limited due to the long period, different number of deliveries over years and lack of other obstetric data (gestational age, maternal BMI, Apgar score as neonatal outcome, coexisting comorbidity, need for analgesia, onset of labor, duration of labor stages and pregnancy complications) due to the lack of protocols (1950-1990), our results demonstrated the value of MRMPP in perineal tear reduction.

Professional assistance at the end of the second labor stage is currently divided into three 'philosophies' rooted in different countries in line with their respective tradition and perception, as follows: 'hands-on', 'hands-poised' and 'hands-off' technique, i.e. spontaneous delivery without hands involvement. RMPP or MRMPP have been recommended as MPP 'hands-on' method by earlier and modern European and AngloSaxon textbooks ${ }^{2-5}$. One randomized controlled study failed to demonstrate any difference in the occurrence of OASIS comparing deliveries with MRM and those using the 'standard care' technique ${ }^{7}$. The rate of perineal tear grades III and IV was as high as $5.5 \%$ in the first group as compared with the still high figure of $4.4 \%$ in the group using the 'standard care' technique. However, the authors performed MRM during contraction, which was not suggested in the original technique and was not used in the deliveries analyzed. The greater perineal load along with Ritgen maneuver during contraction must have contributed to those quite poor results. Myrfield et al. also describe Ritgen technique as controversial, but they fail to interpret Ritgen's recommendations and modifications correctly ${ }^{8}$. In fact, it is not true that early fetal head extension is stimulated by Ritgen maneuver because fetal head has already come out, thus having extended vaginal introitus and placed the hypomochlion under the symphysis. In this way, fetal head does not turn back in-between labor pains and is delivered by its least suboccipitobregmatic diameter.

Recent studies demonstrated that the use of the Scandinavian MPP model led to central and peripheral perineal tone reduction and significantly decreased the rate of perineal tear grades I and II, OASIS, prophylactic episiotomies and perineal tears ${ }^{9}$. However, a stereophotogrammetric study showed perineal defor- 
mity during final labor stage, resulting in recommendation on the right-hand usage, i.e. fingers in MPP in order to reduce perineal strain and prevent perineal tear ${ }^{10}$. On the other hand, Smith et al. report an increased incidence of soft birth canal tear, which was significantly more common in primiparae, grade I tear more common in homebirths, and grades II, III and IV in hospital births ${ }^{11}$. These results were probably influenced by the traditional use of hands-off or handspoised modality in delivery technique.

Stoeckel reports on $4 \%-25 \%$ of perineal tears ${ }^{3}$. According to German obstetric statistics for 2011 including 432,944 deliveries, the rate of complication free deliveries (without soft birth canal tears) was $38.4 \% \%^{12}$, whereas in Austria, the same rate for 2011 was $56.4 \%{ }^{13}$. Moreover, Australian maternal-fetal medicine reports revealed a $71.5 \%$ rate of genital trauma in vaginal delivery, mostly grades I and II, and $2.4 \%$ of $\mathrm{OASIS}^{14}$. National statistics for Croatia could not be presented since there are only sporadic reports on perineal tears from some departments and tertiary perinatal centers ${ }^{15}$.

Recent Scandinavian studies point to the problem of correct tear diagnosis and classification since their lack may influence an increase in the incidence of tears in these countries ${ }^{6,7,9}$. Many of the risk factors for OASIS cannot be modified but there is evidence that MPP used in the last phase of the second labor stage could decrease the incidence of OASIS, which is a well established indicator of the maternity care quality ${ }^{16,17}$. Having all this in mind, it is clear that additional effort should be invested in correct exploration, visualization and perineal tear classification in order to enable appropriate tear management and to prevent early and late complications of both known and occult obstetric injuries.

According to Laine et al., MPP reduced the incidence of OASIS from $4.1 \%$ to $2.3 \%$ upon the introduction of the national MPP program at all maternity wards in Norway. Of these, anal incontinence occurred in $21 \%$ of cases 9 . Since the introduction and modification of MPP, OASIS has been reduced by $50 \%$ in Nordic countries; it is reasonable to perform skill training at the national level to reduce the short- and longterm OASIS complications ${ }^{9}$. Although some authors claim that the modified Finnish manual protection (Finnish intervention) does not reduce OASIS, other studies confirmed that MPP induced reduction of OASIS from $4.4 \%$ to $1.7 \% \%^{18,19}$. A recent study also demonstrated a protective effect of 'hands-on' perineal support in the prevention of OASIS ${ }^{20}$.

In conclusion, MRMPP has been demonstrated to prevent OASIS and reduce significantly grade I-IV perineal tears and the rate of episiotomies. Our investigation showed that modification of MPP concepts requiring minimal equipment could result in faster recovery and more comfortable puerperium. Additional studies should address long-term consequences of the MRMPP technique with special consideration of the possible occult lesions or unrecognized OASIS with complications.

\section{References}

1. Habek D. Povijest primaljstva, porodništva i ginekologije bjelovarskog kraja. [History of Midwifery, Obstetrics and Gynecology in Bjelovar-Bilogora County]. Bjelovar, Croatia: Čvor Bjelovar, 2009. (in Croatian)

2. Martius H. Lehrbuch der Geburtshilfe. Stuttgart: Georg Thieme, 1958;333. (in German)

3. Stoeckel W. Lehrbuch der Geburtshilfe. Jena: Gustav Fischer 1956;871.

4. Pschyrembel W, Dudenhausen W. Practic Obstetrics with Obstetrics Operations. $15^{\text {th }}$ edn. Berlin-New York: Walter de Gruyter, 1986;253.

5. Cunningham FG, MacDonald PC, Gant NF, et al. Williams Obstetrics. $1^{\text {th }}$ edn. New York: Prentice-Hall International, Inc., 1993;381-2.

6. Sultan AH, Kamm MA, Hudson CN, Thomas JM, Bartram CI. Anal-sphincter disruption during vaginal delivery. N Engl J Med. 1993;329:1905-11.

7. Jönsson ER, Elfaghi I, Rydhström H, Herbst A. Modified Ritgen's maneuver for anal sphincter injury at delivery: a randomised controlled trial. Obstet Gynecol. 2008;112(Pt 1): 212-7. doi: 10.1097/AOG.0b013e31817f2867.

8. Myrfield K, Brook C, Creedy D. Reducing perineal trauma: implications of flexion and extension of the fetal head during birth. Midwifery. 1997;13(4):197-201.

9. Laine K, Skjeldestad FE, Sandvik L, Staff AC. Incidence of obstetric anal sphincter injuries after training to protect the perineum: cohort study. BMJ Open. 2012;17;2-5.

10. Zemčik R, Karbanova J, Kalis V, Lobovský L, Jansová M, Rusavy $Z$. Stereophotogrammetry of the perineum during vaginal delivery. Int J Gynecol Obstet. 2012;119:76-80. doi: 10.1016/j.ijgo.2012.05.018.

11. Smith LA, Price N, Simonite V, Burns EE. Incidence of and risk factors for perineal trauma: a prospective observational study. BMC Pregnancy Childbirth. 2013;13:59.

12. National evaluation for birth injuries in clinical obstetrics in 2011. Aqua Institute, Germany, 2012. 
13. Birth Register Styria 2011. Annual Report. G. M. B. H. KAGes Management Quality Management. Graz, 2011;39.

14. Queensland Clinical Guidelines. Maternity and Neonatal Clinical Guideline. Perineal care. Queensland Government, 2010; 6-12.

15. Obstetric statistics of University Department of Gynecology and Obstetrics, Sveti Duh Clinical Hospital, Zagreb (for internal use), 2011.

16. Bulchandani S, Watts E, Sucharitha A, Yates D, Ismail KM. Manual perineal support at the time of childbirth: a systematic review and meta-analysis. BJOG. 2015;122:1157-65. doi: 10.1111/1471-0528.13431.

17. Edozien LC, Gurol-Urganci O, Cromwell DA, Adams EJ, Richmond DH, Mahmood TA, van der Meulen JH. Impact of third- and fourth-degree perineal tears at first birth on subsequent pregnancy outcomes: a cohort study. BJOG. 2014; doi:10.1111/1471-0528.12886.

18. Ostergaard P, Madsen ML, Skriver-Moller AC, Overgaard $\mathrm{CH}$. Does the Finnish intervention prevent obstetric anal sphincter injuries? A systematic review of the literature. BMJ Open. 2015;5:e008346. doi_10.1136/bmjopen-2015-008346.

19. Leenskjold S, Hoj L, Pirhonen J. Manual protection of the perineum reduces the risk of obstetric anal sphincter ruptures. Dan Med J. 2015;62(5):1-5.

20. De Leeuw JV, Struijk PC, Vierhout ME, Wallenburg HC. Risk factors for third degree perineal ruptures during delivery. BJOG. 2001;108:383-7.

Sažetak

\section{ŠEZDESET GODINA PRIMJENE MODIFICIRANE MANUALNE PERINEALNE ZAŠTITE PO RITGENU}

\section{Habek, A. Tikvica Luetić, I. Marton, M. Prka, G. Pavlović, Ž. Kuljak, D. Švanjug i Z. Mužina}

Cilj istraživanja bio je prikazati 60-godišnje iskustvo u modificiranoj manualnoj perinealnoj zaštiti po Ritgenu u odnosu na razdore međice. Retrospektivna opservacijska klinička studija (1950.-2010.) analizirala je petogodišnje intervale učinka modificirane Ritgenove tehnike perinealne zaštite (kontrolirana fetalna defleksija lijevom rukom uz sinkronu redukciju napetosti međice desnom rukom koja je ispružena s desne strane međice i vulve, bez tiskanja rodilje) na peripartalne razdore međice u rodilištu Opće bolnice u Bjelovaru, Hrvatska. Ukupna stopa razdora međice bila je manja od 5\% do 2000. godine. Stopa razdora I. stupnja bila je vrlo niska do godine 1995., zatim se povećala na 8,6\% u 2010. godini, ali nikada iznad $10 \%$. Razdori međice II. stupnja nisu prelazili stopu od 2\%, dok su razdori međice III. stupnja bili sporadični i nisu prelazili $0,4 \%$ u ispitivanom materijalu, uz jedan slučaj razdora IV. stupnja. Netaknuta međica bez epiziotomije bila je u rasponu od $96,2 \%$ do 100\% u razdoblju od 1950. do 1960. godine, sa smanjenjem od 46\% u 2010. godini. Ovo istraživanje dokazalo je značajno smanjenje razdora međice svih stupnjeva uporabom modificirane manualne zaštite po Ritgenu.

Ključne riječi: Porođaj, opstetrički; Perineum - ozljede; Analni kanal - ozljede; Laceracije - prevencija i kontrola; Hrvatska 